Please share your stories about how Open Access to this article benefits you.

\title{
Secondary Growth in Vertebraria Roots from the Late Permian of Antarctica: A Change in Developmental Timing
}

\author{
by Anne-Laure Decombeix, Edith L. Taylor, \\ and Thomas N. Taylor
}

2009

This is the published version of the article, made available with the permission of the publisher. The original published version can be found at the link below.

[Citation]

Published version: http://www.jstor.org/stable/10.1086/597784

Terms of Use: http://www2.ku.edu/ scholar/docs/license.shtml 


\title{
SECONDARY GROWTH IN VERTEBRARIA ROOTS FROM THE LATE PERMIAN OF ANTARCTICA: A CHANGE IN DEVELOPMENTAL TIMING
}

\author{
Anne-Laure Decombeix, ${ }^{1}$ Edith L. Taylor, and Thomas N. Taylor \\ Department of Ecology and Evolutionary Biology, and Natural History Museum and Biodiversity Research Center, \\ University of Kansas, Lawrence, Kansas 66045-7534, U.S.A.
}

\begin{abstract}
Permineralized Vertebraria roots from the late Permian of the Central Transantarctic Mountains, Antarctica, are investigated to understand the unusual vascular anatomy of the genus. The specimens range from $\sim 1 \mathrm{~mm}$ to several centimeters in diameter and illustrate all the stages of secondary growth. Our observations confirm previous hypotheses on the development of these roots and suggest that their unique anatomy is the result of a change in developmental timing. Vertebraria is characterized by a vascular cambium that remains discontinuous through several growth seasons, leading to the formation of lacunae alternating in cross section with wedges of secondary vascular tissues. The bifacial nature of the cambium is confirmed by the presence of well-developed secondary phloem composed of longitudinally elongated cells and uniseriate parenchymatous rays. In some of the largest specimens, a continuous vascular cylinder is formed by the differentiation of cambium from parenchymatous cells bordering the lacunae. The new specimens provide additional information on the secondary xylem anatomy and vascular connection to lateral roots.
\end{abstract}

Keywords: Permian, Antarctica, Glossopteridales, roots, Vertebraria, anatomy, development.

\section{Introduction}

Rooting structures are hypothesized to have evolved independently in all the major groups of vascular plants some time during the Devonian (Raven and Edwards 2001). In the lignophyte clade (i.e., progymnosperms and seed plants), roots were probably derived from a stem with a simple, protostelic organization (Beck 2005). Structural adaptations of this ancestral axis, no doubt related to its functions in anchorage and absorption of water and minerals, led to the typical root anatomy of seed plants. Because the organization of lignophyte roots has changed little since the Devonian progymnosperms, they have received significantly less attention than associated stems and reproductive organs. Among the Paleozoic lignophytes, however, root anatomy and morphology have been described for some representative genera, including the Devonian progymnosperm Archaeopteris (Beck 1953) and Carboniferous seed plants, such as Lyginopteris (Williamson 1894; Halket 1932; Krings and Schultka 2000), Medullosa (Steidtmann 1944; Rothwell and Whiteside 1974), Callistophyton (Rothwell 1975; Russin 1981), and Cordaites (Cridland 1964). While it is difficult to assess the systematic value of root characters in these plants, the study of root systems provides more accurate reconstructions of the habit and development of fossil plants, as well as offering insights on the environment in which these plants lived. In this article, we present new data on secondary growth in Vertebraria, a morphogenus found in Gondwanan floras throughout the Permian

\footnotetext{
${ }^{1}$ Author for correspondence; e-mail: aldecomb@ku.edu.
}

Manuscript received November 2008; revised manuscript received January 2009. and interpreted as the root system of the glossopterid gymnosperms (Gould 1975).

\section{Historical Account}

Even though Vertebraria has been reported by numerous authors since the nineteenth century because of its local abundance and distinctive morphology, its exact nature and biological affinities have remained uncertain for most of its history. The genus was proposed by Royle for compressions of axes with a vertebrae-like appearance from the Permian of India. Royle (1839) provided enough illustrations to create a valid genus, with the type species Vertebraria indica, but he did not provide an interpretation of the specimens. McCoy (1847) provided a diagnosis for the genus based on axes from New South Wales that he assigned to a new species, Vertebraria australis. He interpreted Vertebraria as a slender stem bearing whorls of cuneiform leaves and viewed it as closely allied to Sphenophyllum (Sphenopsida). This idea was not widely accepted, and most paleobotanists viewed Vertebraria as representing a leafless axis with an unusual anatomy, belonging either to a fern or to a gymnosperm (Zeiller 1896; Oldham 1897; Seward 1914). Another interpretation was proposed in 1932, when Walton and Wilson (1932) used cellulose acetate peels on coalified specimens and demonstrated that the "leaves" were in fact wedges of secondary xylem separated by empty zones that they interpreted as wide medullary rays. Both the general organization and xylem anatomy supported a gymnosperm affinity. Further studies, notably of compressed and coalified axes from India and Tanganyika (now Tanzania; Sen 1955, 1958; Pant 1956), supported the idea of a gymnosperm axis. Although these studies of compression specimens led to a better understanding of the genus, it was still unclear whether Vertebraria was a stem, a 
rhizome, or a root. The affinities of the plant also remained uncertain. While some reports of Glossopteris leaves borne on Vertebraria axes (see review in Pigg and Taylor 1993) suggested an affinity with the Glossopteridales, there was no indisputable connection found.

The discovery of anatomically preserved specimens in permineralized peat from Antarctica (Schopf 1965; White 1973) and their detailed description by Schopf $(1965,1970,1982)$ marked important progress in understanding this plant. Schopf described Vertebraria as a root with three to nine protoxylem strands, wedges of pycnoxylic secondary xylem with conspicuous growth rings, and a thin cortex. Traces to lateral roots were produced between the xylem wedges. Schopf interpreted the zones between the xylem wedges as what he termed "parenchymatous pockets" that have no equivalent in extant plants. He also hypothesized that the production of a continuous cylinder of wood in the external part of some specimens was the result of initiation of new xylem initials from marginal cells in the parenchymatous pockets. Gould (1975) described new permineralized specimens from the Bowen Basin of Queensland, Australia. He noted that the spaces between the wood wedges were apparently empty during active growth and suggested that they represented an adaptation to living in waterlogged soils. Gould also compared the wood of Vertebraria with that of Araucarioxylon trunks from the same deposits and concluded that they belonged to the same plant that probably bore Glossopteris leaves. Accumulated data from the study of compression and permineralized specimens finally led to the classical textbook reconstruction of Vertebraria as the root system of a swamp-dwelling glossopterid tree (Gould and Delevoryas 1977).

More recently, Neish et al. (1993) provided a developmental study of Vertebraria and, for the first time, documented the early stages of growth on the basis of permineralized specimens from East Antarctica. They confirmed the root characteristics of Vertebraria, including the presence of an exarch actinostele and an endodermis, and further illustrated the anatomy of young roots and the onset of secondary growth.

This historical review suggests that since its first description, Vertebraria has received a great deal more attention than any other fossil root. Nevertheless, several points regarding its anatomy and development remain poorly known. The large number of anatomically preserved specimens collected since 1970 in the central Transantarctic Mountains, Antarctica, is a unique opportunity to further investigate this genus. As a result of detailed anatomical study of some particularly wellpreserved specimens, we confirm mechanisms of secondary growth in Vertebraria and propose a synthesis of the developmental events producing the unique organization seen in this root. This article also provides new anatomical data, including the first description of secondary phloem and the vascular connection between parent and lateral roots.

\section{Material and Methods}

The specimens described in this article are preserved in permineralized peat collected from Skaar Ridge, Beardmore Glacier region, central Transantarctic Mountains, Antarctica

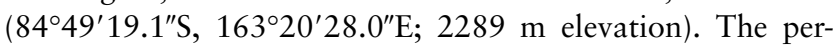

mineralized peat occurs within the Buckley Formation of the Beacon Supergroup and is considered to be Late Permian in age on the basis of palynomorphs and associated compression floras (Farabee et al. 1991).

Vertebraria roots are the most abundant plant remains in the permineralized peat at Skaar Ridge. They show no particular orientation in the peat blocks, with branching occurring in all directions. The following description is based on the observation of numerous specimens, ranging from minute rootlets less than $1 \mathrm{~mm}$ in diameter to large roots with several centimeters of wood. The peat also contains roots with no lacunae in the wood, similar to the "solid-cylinder Vertebraria" of Neish et al. (1993). Because these specimens present distinct anatomical characters and stages of development, and because no connection between a Vertebraria and a solid-cylinder Vertebraria has been observed, we will not include them in this study. Further investigation is needed to elucidate whether these solidcylinder Vertebraria represent roots of a different taxon or a different type of root produced by the same plant.

Serial cellulose acetate peels were made using the standard technique (Galtier and Phillips 1999). Specimens were cut into slabs, and polished surfaces were etched for 1-5 min in 49\% hydrofluoric acid and then rinsed and peeled. Selected peels were mounted in Eukitt on microscope slides for observation. Digital images were taken under reflected light using a Leica (Leica Microsystems, Wetzlar, Germany) DC500 digital camera attachment on a Leica MZ16 stereomicroscope and with transmitted light using a Leica DC500 digital camera attachment on a Leica DM5000 B compound microscope. Photographs figure $3 A$ and $3 B$ were taken on an unmounted peel. Images were processed using Adobe Photoshop CS (1999-2003, Adobe Systems). Cell and tissue measurements were made using Wright Cell Imaging Facility's ImageJ software (Rasband 1997-2008). Ring structure was analyzed using Denne's (1989) formula for earlywood-latewood boundary. Specimens, peels, and slides used in this study are deposited in the Paleobotanical Collections, Natural History Museum and Biodiversity Research Center, University of Kansas, under the specimen accession numbers 11324, 11642, 11645, 11648, 11654, 15479, 15491, 15529, 15542, 15549, 15630, 15695, 15855, and CB447, and slide accession numbers 2315023256 and 26367-26373. Several specimens are present on most slides and thus share the same slide number.

Note on terminology. The term "lacunae" is used here for the structures termed "airspaces" by previous authors. As we will discuss later, it is unclear that these structures served as air channels; therefore, we will use the more neutral term "lacunae" in the description and discussion.

\section{Results}

\section{Anatomy of Young Roots with Primary Growth Only (Fig. 1)}

The youngest developmental stages observed correspond to axes $1 \mathrm{~mm}$ in diameter or less (fig. $1 A$ ). These rootlets are very abundant locally in the peat and are usually highly branched. Some grow in decaying wood or in the lacunae of larger Vertebraria axes (fig. $2 G$; fig. $8 D, 8 E$ ). 

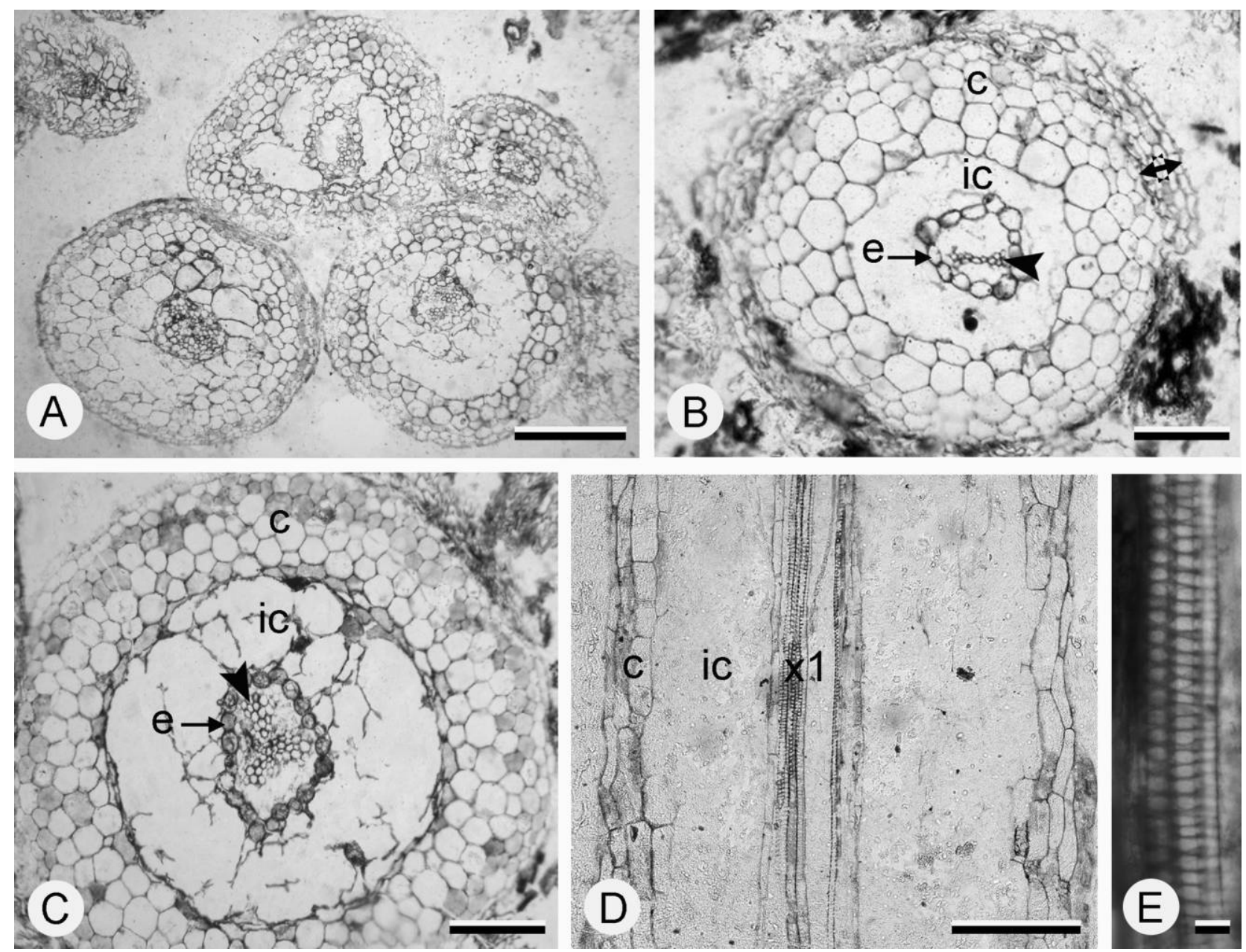

Fig. 1 Young roots of Vertebraria. A, Permineralized peat with several young roots in cross section. Slide 23255, scale bar $=500 \mu \mathrm{m}$. $B$, Cross section of a young diarch root showing outer cortex, empty inner cortex, endodermis, and stele with only primary xylem preserved. Slide 23177, scale bar $=100 \mu \mathrm{m}$. C, Cross section of a young triarch root showing outer cortex, degraded inner cortex, endodermis, and primary xylem. Slide 23189 , scale bar $=200 \mu \mathrm{m}$. D, Longitudinal section showing outer cortex, endodermis, and stele with primary xylem with spiral thickenings. Slide 23224, scale bar $=200 \mu \mathrm{m}$. E, Detail of the primary xylem tracheids ornamentation in longitudinal section. Slide 23224 , scale bar $=20 \mu \mathrm{m}$. $c=$ outer $\operatorname{cortex} ; e=$ endodermis; $i c=$ inner cortex; $x 1=$ primary xylem; arrowhead $=$ protoxylem; double-headed arrow $=$ possible additional layer outside the outer cortex.

Epidermis and cortex. The rhizodermis is composed of a single row of tangentially elongated cells. No root hairs or stomata have been observed in any specimens; however, unless highly concentrated, it is unlikely they would be conspicuous in even closely spaced serial peels. Two zones can be distinguished in the cortex. The outermost portion (outer cortex) is composed of four or five layers of compact parenchyma cells (fig. $1 B, 1 C$ ) that are polygonal in transverse section and 28$130 \mu \mathrm{m}$ in diameter. The largest cells are located toward the center of the axis. In longitudinal section, they appear higher than wide (fig. $1 D$ ). In most specimens, the outer cortex persists after the initiation of secondary growth (fig. $2 A, 2 D, 2 F)$, possibly as a result of cell divisions that accommodate the increasing diameter of the vascular tissues. An additional layer of parenchyma might be present outside the outer cortex (fig. $2 B$, double-headed arrow). This layer, only a few cells thick, is absent or badly preserved in most specimens.
The inner part of the cortex is composed of parenchyma cells of irregular size and shape. The absence of this tissue in most rootlets may be the result of early degradation rather than an artifact of preservation since remains of cell walls can be seen in the best-preserved specimens (fig. 1C). Inside this layer is a well-preserved endodermis. Cells of this layer are circular and 27-55 $\mu \mathrm{m}$ wide in transverse section (fig. $1 B, 1 C$ ). These cells have both Casparian bands and suberin lamellae. Remains of the endodermis can still be identified in some specimens with secondary growth, though more rarely than the outer cortex.

Vascular cylinder. The pericycle is composed of several layers of parenchyma cells. In transverse section, the youngest roots show isolated protoxylem strands composed of two to four cells. In slightly older roots, the centripetal maturation of metaxylem tracheids connects these strands to form an exarch actinostele (fig. $1 B, 1 C$ ) with two to seven protoxylem strands. The smallest protoxylem cells are $6-10 \mu \mathrm{m}$ in diameter and dis- 

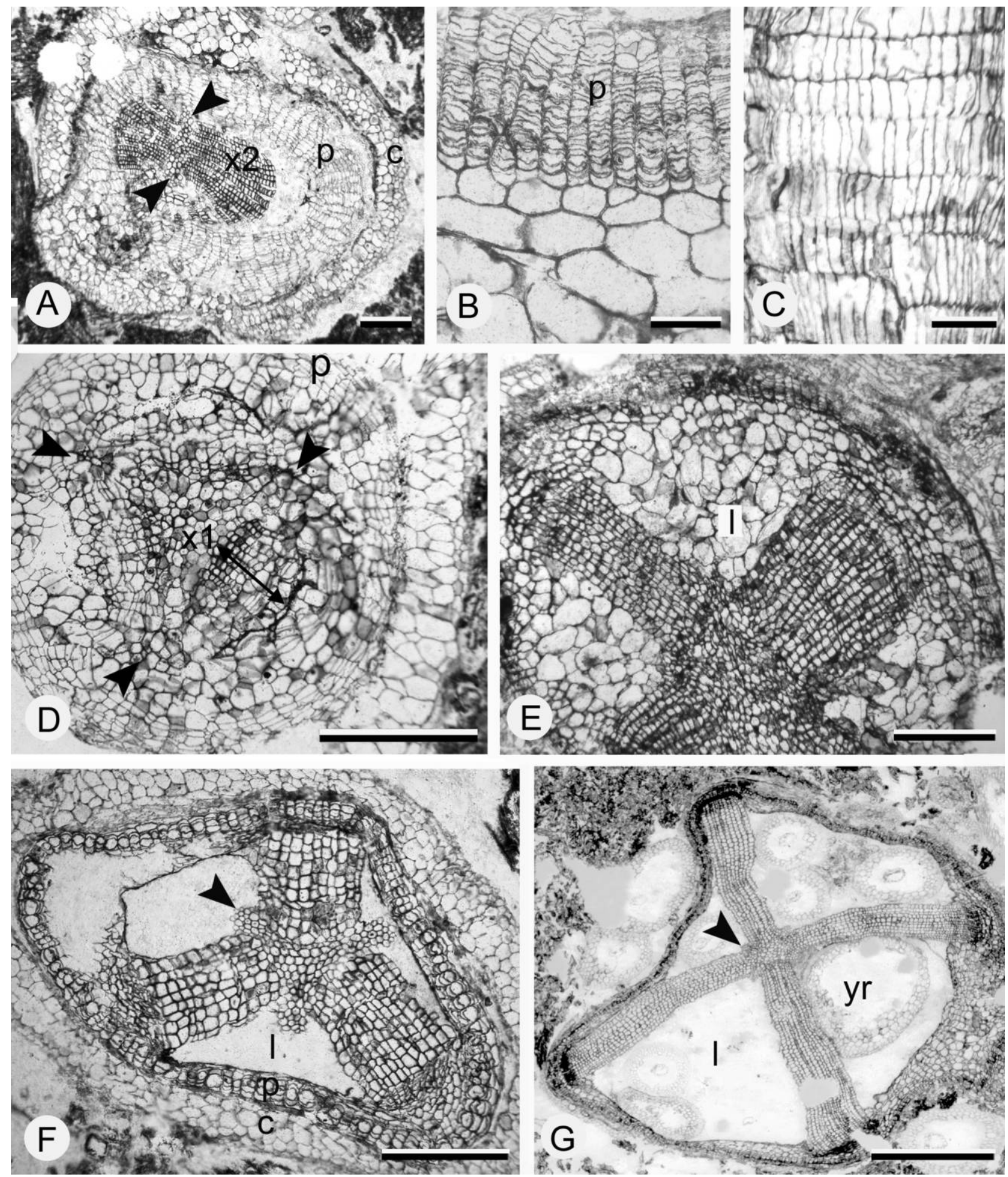

Fig. 2 Vertebraria roots with secondary growth. A, Diarch root with secondary xylem wedges, a well-developed periderm, and the remains of the outer cortex. Slide 23214, scale bar $=500 \mu \mathrm{m}$. B, Transverse section of the periderm. Note phelloderm cells on the inner side. Slide 23189, scale bar $=100 \mu \mathrm{m}$. C, Longitudinal section of periderm showing storied cells. Slide 26373 , scale bar $=100 \mu \mathrm{m}$. $D$, Triarch root showing the beginning of secondary growth with secondary vascular tissues (double-headed arrow), periderm, and the remains of the outer cortex. Slide 23252 , scale bar $=500 \mu \mathrm{m}$. E, Detail of a tetrarch root with well-developed wedges of wood and parenchyma in the lacunae. Slide 23172 , scale bar $=500 \mu \mathrm{m} . F$, Triarch root with empty lacunae. Slide 23171, scale bar $=500 \mu \mathrm{m}$. G, Tetrarch root with empty lacunae. Note young roots growing inside the lacunae, which probably happened after deposition. Slide 23165 , scale bar $=2 \mathrm{~mm} . c=$ outer cortex; $l=$ lacuna; $p=$ periderm; $x 1=$ primary xylem; $x 2=$ secondary xylem; $y=$ young root; arrowheads $=$ protoxylem. 
play annular to spiral thickenings (fig. $1 D, 1 E$ ). Metaxylem tracheids are $10-68 \mu \mathrm{m}$ in diameter. In some specimens with five and six protoxylem strands, the central part of the axis sometimes forms a pseudopith with metaxylem tracheids separated by empty spaces that might correspond to degraded parenchyma. Primary phloem is rarely preserved and when present is crushed. In the youngest specimens, where the vascular tissues are just beginning to differentiate, strands of primary phloem alternate with protoxylem elements. What is interpreted as obliterated primary phloem often appears as a distinct dark zone in axes where secondary growth has begun (fig. 2D).

\section{Development and Anatomy of the Secondary Cortex (Fig. 2A-2C)}

The phellogen differentiates from the pericycle just inside the endodermis as determined by the remains of endoderm cells present just outside the periderm in some young specimens. The phellogen appears to have functioned before or at the same time as the vascular cambium since a well-developed (up to 10 cells) periderm can be identified even in small roots (fig. $2 A$ ). In larger roots, the periderm appears as a thin continuous layer around the axis (fig. 2G). There is no evidence of lenticels. In transverse section, periderm cells are larger in tangential than radial diameter (fig. $2 B$ ), with size ranges of $10-44 \mu \mathrm{m}$ and 6-23 $\mu \mathrm{m}$, respectively. In longitudinal section, these cells are higher than wide and have a storied aspect (fig. 2C). In the best-preserved specimens, parenchymatous cells corresponding to the phelloderm are preserved on the inner side of the periderm (fig. $2 B$ ).

\section{Development and Anatomy of the Secondary Vascular Tissues (Figs. 2-7)}

Figure $2 D$ illustrates a triarch root after secondary growth has been initiated. Tissue development is more conspicuous on one side of the root, and it is interesting to note that both periderm and secondary vascular tissue formation is more advanced on this side. The vascular cambium first appears on the inner side of each primary phloem strand and begins to produce secondary xylem elements inwardly and secondary phloem toward the outside (fig. 2D). The newly formed wedges of secondary xylem alternate with the protoxylem strands while the regions facing the protoxylem strands are occupied by parenchymatous cells that lack a definite arrangement (fig. 2E). The radial growth of the woody wedges results in the expansion, and in most cases, the destruction of this parenchymatous tissue. The resulting lacunae (fig. 2F, 2G) are the most distinctive feature of Vertebraria roots. In diarch roots, where the mechanical constraints are less important, the parenchymatous tissue is sometimes still present after significant secondary development. In some larger specimens, the lacunae become closed and a continuous cylinder of wood is produced in the external part of the root.

Secondary xylem. The secondary xylem is composed of tracheids and uniseriate, parenchymatous rays. There is no evidence of vertical parenchyma. In transverse section, secondary xylem tracheids are square to polygonal in outline (fig. $3 A, 3 B$ ). They have a radial diameter of $7-50 \mu \mathrm{m}$, with an average of 25-35 $\mu \mathrm{m}$, depending on the specimen. Ray cells are typically ovoid to rectangular, sometimes with opaque contents. In one specimen (CB447), we observed a zone in which the number of tangential tracheid rows is locally reduced, giving an hourglass shape to the rows of secondary xylem tracheids. Specimens with a sufficient amount of secondary wood display growth rings (fig. $3 A, 3 B$ ). They are narrower and often more asymmetric in the outer part of large roots, especially in the zone just outside closed lacunae. Some of the rings are interpreted as false rings, and these are characterized by a few layers of tracheids with reduced radial diameters (fig. 4, arrow $A$ ). These rings are often discontinuous. They are present in most of the specimens, even small ones. Other rings, however, appear to be true rings (fig. $3 B$; fig. 4 , arrow $B$ ). They are characterized by a zone of tracheids with uniform diameters and a zone of two to four layers of tracheids with a significantly reduced $(<15 \mu \mathrm{m})$ radial diameter. When using Denne's (1989) formula to calculate the amount of latewood, our measurements suggest that the decrease in radial diameter results from a smaller overall cell diameter with no significant change in wall thickness (fig. 4 , arrow $B$ ).

In tangential section tracheid walls are always unpitted. Rays are uniseriate (fig. 3C) or occasionally partly biseriate in the wood of the largest specimens. The maximum ray height is 10 cells, but in most specimens, rays higher than four cells are absent. Measurements from three specimens and 180 rays give a mean height of 1.4 cells, with $\sim 70 \%$ of the rays unicellular in tangential section (fig. 5). The percentage of unicellular rays can vary slightly between specimens, however. Ray cells are oval in tangential section and measure 9-23 $\times 21-35 \mu \mathrm{m}$. In radial section, secondary xylem tracheids display one to seven rows of bordered pits showing different arrangements. Rarely, the pitting is uniseriate with circular pits spaced on the wall. In almost all specimens examined, all tracheids exhibit multiseriate pitting, with pits forming groups of one to five horizontal rows (fig. $3 D, 3 E$ ). Pits of two successive horizontal rows are generally alternate. The pit aperture is slitlike to elliptical, horizontal or slightly oblique, and measures $\sim 5 \times 3 \mu \mathrm{m}$. Cross-field pits are oval to elongated, sometimes with a scalariform or reticulate aspect (fig. 3F).

Cambium and secondary phloem. In a few well-preserved specimens, a vascular cambium can be recognized external to the secondary xylem wedges (fig. $3 G$ ). It consists of a few rows of crushed, thin-walled cells with a reduced radial diameter. Secondary phloem is located external to these cells and is often better preserved than the cambial zone. This tissue is characterized by rows of radially aligned cells. In transverse section, most cells have thick walls and appear similar to secondary xylem tracheids, but these presumed sieve cells are slightly larger and have a more rounded shape (fig. 6A). A few thin-walled cells corresponding to parenchymatous, uniseriate phloem rays occur opposite secondary xylem rays (fig. 6A). The most peripheral portion of the secondary phloem is always crushed. In longitudinal section, the secondary phloem is characterized by elongated cells (fig. 6B) similar to sieve cells, but no sieve areas have been identified.

Lacunae. The lacunae in the secondary xylem are filled with large parenchyma cells during the early stages of secondary growth (fig. 2E) but then become empty as the parenchymatous tissue dissociates during the enlargement of the wedges of wood. In most of the largest roots, lacunae appear closed in transverse section, and there is a continuous cylinder of wood formed in the most external part of the root (fig. 6C). This is not always the case, however, as in some specimens the xylem wedges may extend up to $7 \mathrm{~cm}$ in diameter with no evidence of closing. There is no indication that the closure of the lacunae can be linked to the root diameter. For ex- 

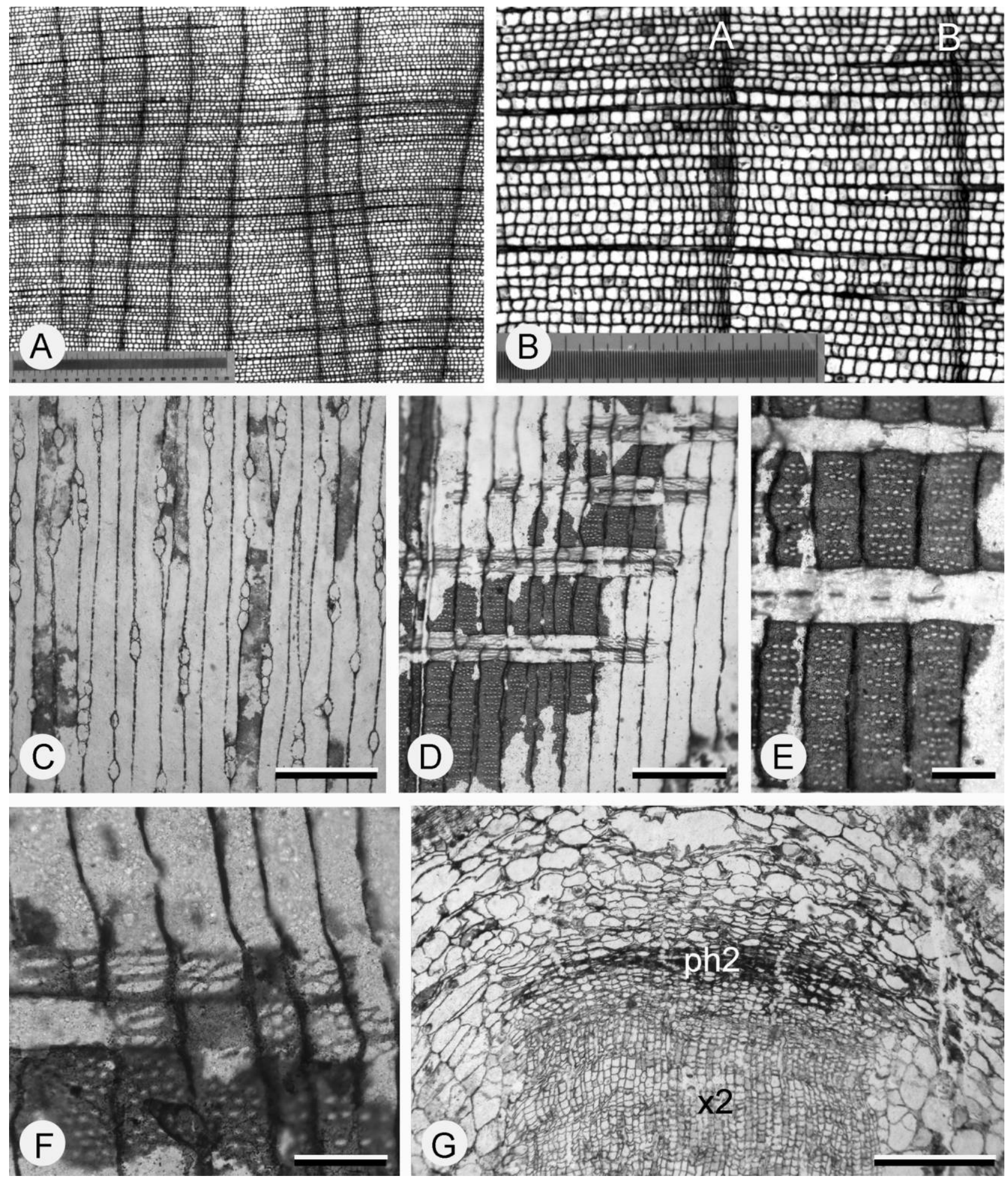

Fig. 3 Vertebraria secondary xylem and cambium zone. A, Transverse section of the external part of an old root with the secondary xylem showing rings. Specimen CB447, peel B-CB2, scale in millimeters. B, Detail of a growth ring in an old root with a small amount of latewood. Specimen CB447, peel B-CB2, scale in millimeters. C, Tangential section of wood showing small, uniseriate rays. Slide 26370 , scale bar $=200 \mu \mathrm{m}$. $D$, Radial section of wood showing multiseriate pitting on the tracheid walls and low rays with cross-field pitting. Slide 26369, scale bar $=200$ $\mu \mathrm{m}$. E, Detail of tracheid pitting. Slide 26369, scale bar $=200 \mu \mathrm{m}$. F, Detail of cross-field area showing oval to elongated pits (above). Compare with tracheid pits (below). Slide 26369, scale bar $=50 \mu \mathrm{m}$. G, Transverse section of the end of a xylem arm showing secondary phloem. $x 2=$ secondary xylem; $p h 2=$ secondary phloem. Slide 23189 , scale bar $=500 \mu \mathrm{m}$. 


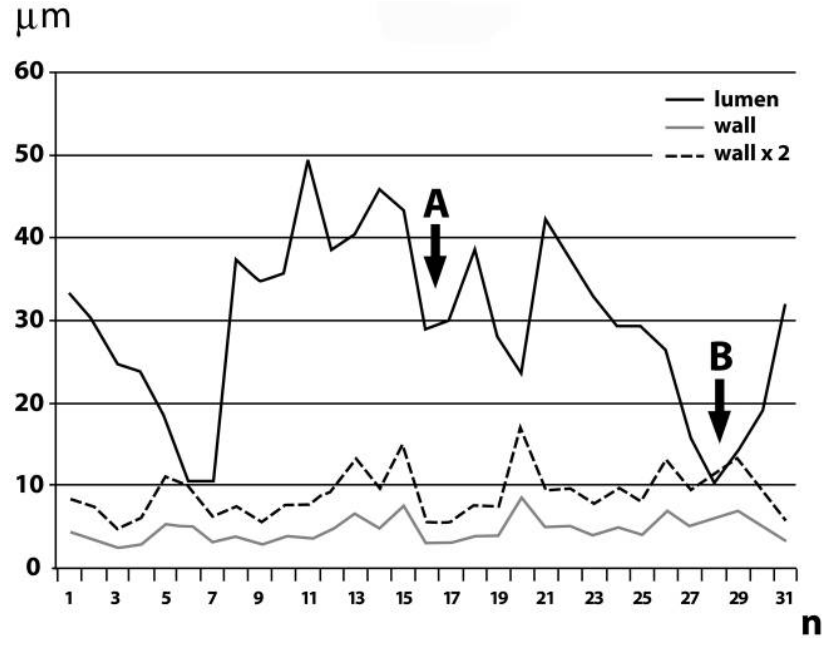

Fig. 4 Ring analysis in specimen CB 447. Using Denne's (1989) formulas, measurements of lumen radial diameter (dark line) and wall thickness (gray line) or double wall thickness (dotted line) are shown. The earlywood-latewood boundary is located where either of the wall thickness lines cross the lumen diameter line. Point $A$ indicates a zone where tracheid diameters decrease slightly, but there is no latewood, and diameter subsequently increases. Point $B$ indicates a ring boundary with a small amount of latewood (three tracheids).

ample, we observed two tetrarch specimens with lacunae closing at, respectively, $7 \mathrm{~mm}$ and $20 \mathrm{~mm}$ from the center of the axis.

The closure of lacunae takes place by several mechanisms. One of these is inferred from the observation of large specimens with closed lacunae (e.g., fig. 6C). Although the individual wedges of wood are enlarging radially toward the exterior, indicating an enlargement of the corresponding cambial arcs, the closure of the lacuna happens before the zone where two adjacent wood wedges would theoretically come in contact. In these specimens, the lacunae are empty but along the periphery are two to three rows of parenchymatous cells. The secondary xylem that will develop between the wedges of wood and eventually close the lacuna is composed of rows of tracheids and rays produced by a cambium that initiates in this parenchymatous tissue (fig. 6D). Thus, apparently there is a differentiation of the parenchymatous tissue into a vascular cambium, which completes the cambial cylinder around the axis.

The second mechanism by which lacunae are formed is based on serial cross sections of a small tetrarch axis in what we interpret as the transition zone between root and stem. This axis is $\sim 3 \mathrm{~mm}$ wide and occurs close to a stem of similar size (fig. $6 E$ ). The sections show both a change in the anatomy of the Vertebraria axis and a connection between this axis and the nearby stem. The most basal sections show typical Vertebraria anatomy, with four wedges of secondary xylem alternating with a similar number of lacunae. In subsequent sections, we observed an initial closure of the lacunae by enlargement of the extremity of the xylem wedges (fig. $4 F$ ), resulting in a reduction of the size of these spaces (fig. $6 \mathrm{G}$ ) until they completely disappeared. This specimen illustrates the transition between a Vertebrariatype axis and an axis with a normal woody cylinder. Contrary to the first pattern of closure, lacunae here are sealed off when the two wedges of wood adjacent to the lacuna come in contact (fig. 6G).

\section{Relative Importance of the Different Tissues (Fig. 7)}

To quantify the relative importance of the main tissues at the different stages of development, their cross-sectional areas were measured in five tetrarch roots (fig. 7). Root A has only primary tissues. More than $90 \%$ of the root cross-sectional area (RCA) is composed of the parenchymatous outer $(52 \%$ RCA) cortex and degrading inner cortex (40\% RCA). The remainder of the surface is occupied by the endodermis and stele. Root B has well-developed metaxylem but no secondary vascular tissues, although the periderm is beginning to develop. In this axis, the parenchymatous cortex still represents $69 \%$ of the RCA. The secondary cortex is $10 \% \mathrm{RCA}$, and the primary vascular tissues of the stele represent $21 \%$ RCA. Root $\mathrm{C}$ (see also fig. $2 E$ ) has both periderm and secondary vascular tissue. The remnants of the outer cortex have been shed. The lacunae are filled with parenchyma and represent $46 \%$ of the RCA. The remainder of the root cross-sectional area is occupied by the primary and secondary vascular tissues $(36 \%$ RCA) and the secondary cortex (18\% RCA). Root D (fig. 2G) shows secondary tissues, and the parenchyma in the lacunae has been dissociated by the radial growth of the wood wedges. In this axis, lacunae represent more than half $(56 \%)$ of the total RCA, vascular tissues represent 24\% RCA, and secondary cortex $20 \%$ RCA. Root E (fig. 6C) exhibits abundant secondary tissue development and closed lacunae. In this axis, lacunae represent $20 \%$ RCA, vascular tissues $67 \%$ RCA, and secondary cortex $14 \%$ RCA.

\section{Branching (Fig. 8)}

Lateral roots are produced opposite the protoxylem strands (fig. 8A-8C) so the vascular connections between parent and lateral root can typically be seen filling in the lacunae in transverse section of roots with secondary growth. In longitudinal section, this produces the transverse woody connections crossing the lacunae and producing the typical vertebrae-like aspect of the genus (fig. 8D).

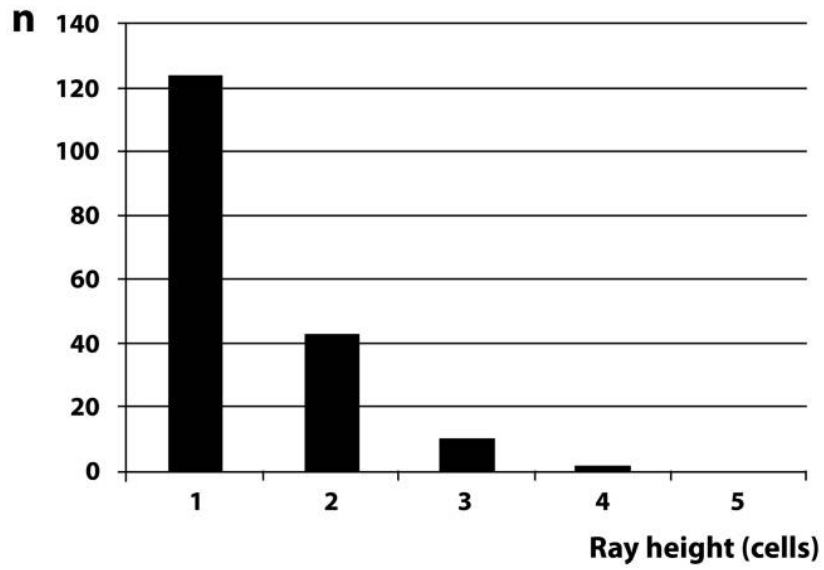

Fig. 5 Ray height measured in tangential section $(n=150)$. All rays are uniseriate. 

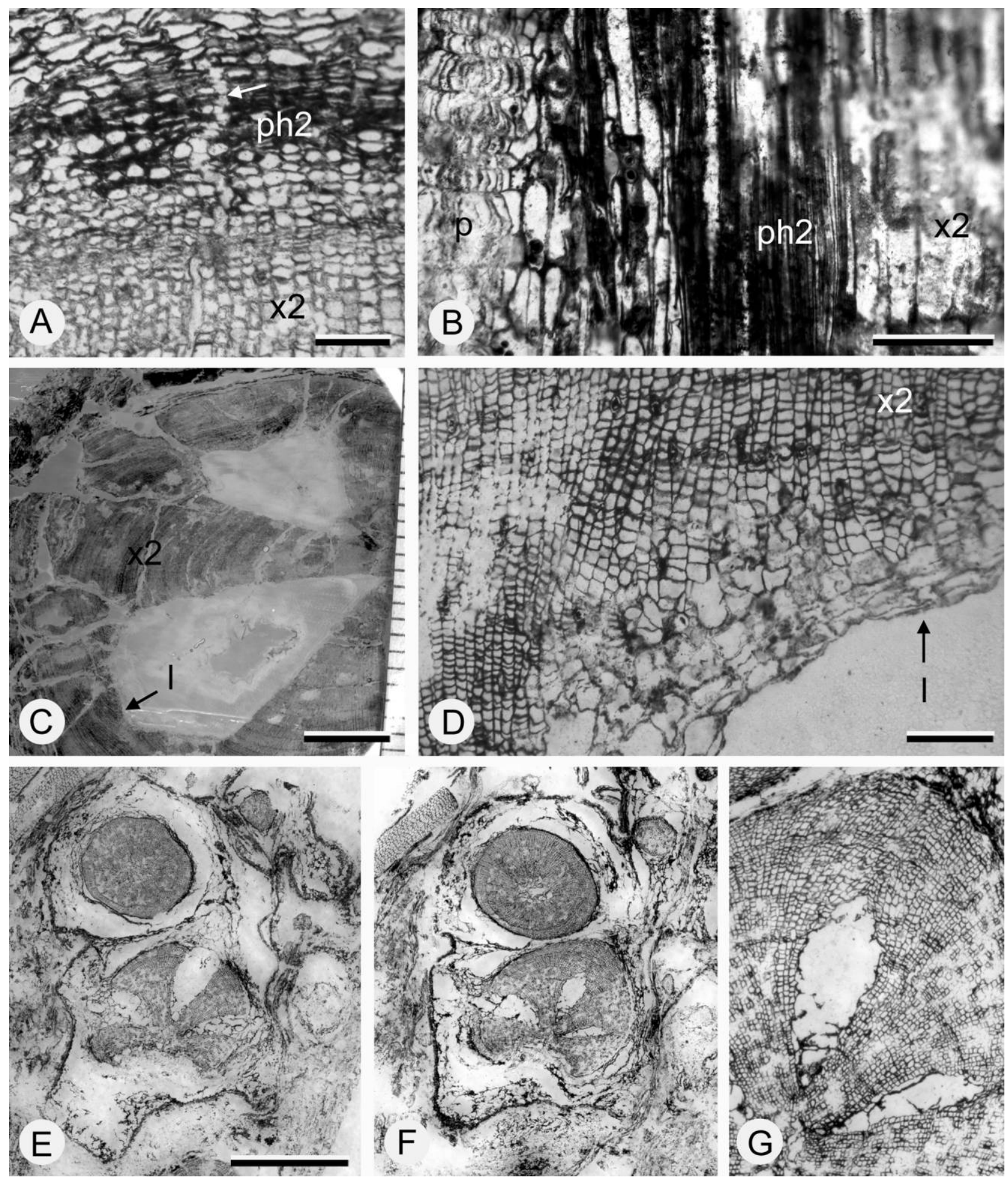

Fig. 6 Secondary phloem anatomy and closure of lacunae. A, Detail of secondary phloem in transverse section with a parenchymatous ray (white arrow). Slide 23189, scale bar $=100 \mu \mathrm{m} . B$, Longitudinal section through phloem. Slide 23174, scale bar $=100 \mu \mathrm{m}$. C, Transverse section of a large tetrarch specimen with lacunae closed at the periphery (arrow). Slide 26367, scale bar $=1 \mathrm{~cm}$. D, Detail of previous section illustrating the parenchymatous zone on the external border of a closed lacunae. Slide 26367 , scale bar $=200 \mu \mathrm{m}$. E-G, Closure of the lacunae in a small specimen. E, Section of the axis with typical Vertebraria anatomy (i.e., lacunate). Note the stem section above. Slide $23204, \mathrm{scale} b a r=2 \mathrm{~mm} . \mathrm{F}$, More proximal section showing closing of lacunae. Slide 23208. G, Detail of closed lacunae in $F$. $l=$ lacunae; $p=$ parenchyma; $p h 2=$ secondary phloem; $x 2=$ secondary xylem. 


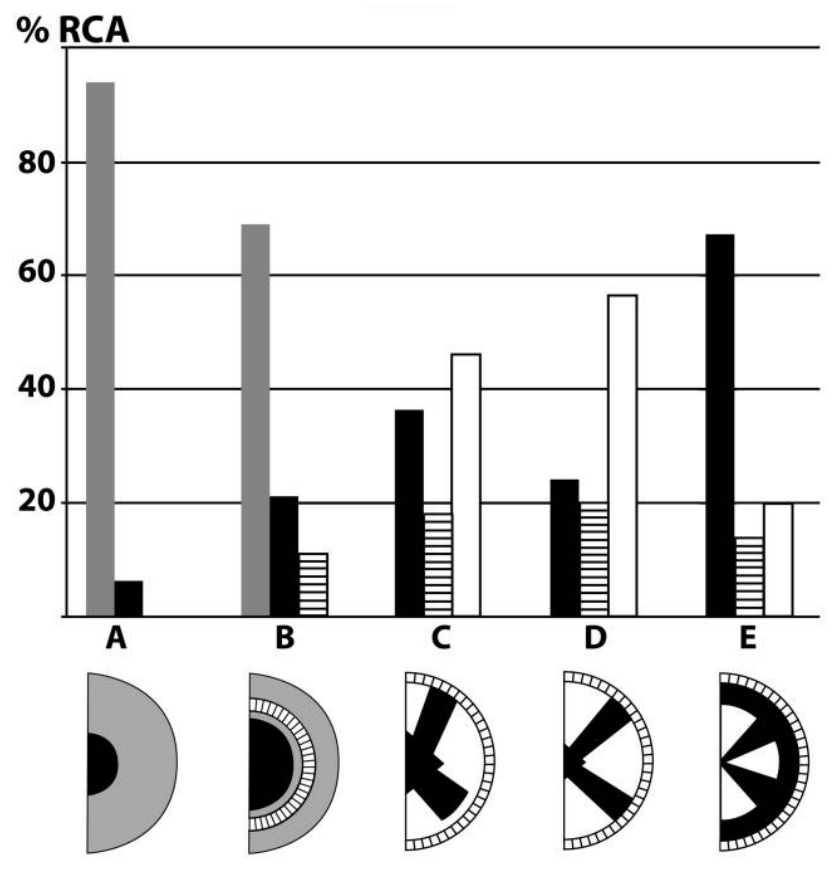

Fig. 7 Cross-sectional area of tissues at different stages of growth. $Y$-axis $=$ proportion of cross-sectional area occupied by different tissues in five tetrarch roots illustrating different stages of growth. Gray = parenchyma (except lacunae parenchyma if present); black = vascular tissues; hatched = periderm; white = lacunae. The drawings (not to scale) correspond to the cross-sectional anatomy of the five roots. $A$, $B=$ young roots with no secondary vascular tissues; $C-E=$ roots with secondary growth. Root diameter: $A=1 \mathrm{~mm} ; B=2 \mathrm{~mm} ; C=3 \mathrm{~mm}$; $D=8 \mathrm{~mm} ; E=50 \mathrm{~mm}$.

In roots with secondary tissue development, there is a connection of both the primary (fig. 8B) and secondary (fig. 8C) vascular tissues. The secondary xylem and phloem of the two adjacent wedges of the parent root are connected to the lateral root. In most of the observed specimens, a single lateral root is produced, while, in a few cases, there are apparently two (fig. $8 E$ ) or three laterals produced at the same location.

\section{Discussion}

\section{Anatomy of Secondary Xylem and Phloem}

Walton and Wilson (1932, p. 202) were the first to describe and to illustrate the presence of secondary xylem in Vertebraria. They described cross-field pits "similar to those on the radial walls of the tracheids," i.e., numerous, oval to circular, and bordered. As a result of this initial report, cross-field pitting has generally been described as consisting of several bordered pits of the araucarioid type (Walton and Wilson 1932; Sen 1958; Gould 1975). Schopf (1965), however, reported the occurrence of simple oval pits, and Pant and Singh (1968, p. 423) described "moderately large oval pits with very slightly developed borders or none." Our own observations indicate that the cross-field pitting may be variable in Vertebraria, and we observed pitting ranging from numerous, circular, bordered pits to one to three elongated pits with a thin or absent border. In some specimens, this variation is present within a single radial section. Cross-field pitting is considered an important taxonomic character in extant gymnosperm woods (IAWA Committee 2004) and is also commonly used for Cenozoic and Mesozoic woods (Philippe and Bamford 2008). In Paleozoic woods, however, this character is not always well documented, and its systematic implications are rather equivocal. In this context, it important to underline that both tracheid and cross-field pitting in our specimens differ from the typical araucarioid type to which Vertebraria wood has traditionally been assigned. Because of the variation occurring in a single specimen, pitting does not seem to be a useful character to investigate either the possible presence of different species of Vertebraria or the affinities of Vertebraria with associated stems or trunks.

Pigg and Taylor (1993) described small leafy axes of Glossopteris skaarensis from the Skaar Ridge locality. The secondary xylem of these axes agrees with that of Vertebraria in the possession of uniseriate rays that are one to a few cells high. Radial pitting on the tracheids consists of uni- to biseriate bordered pits, either oval and spaced, or hexagonal and crowded. The cross-field pitting is best described as transitional between cupressoid and taxodioid. This anatomy is simpler than what is observed in Vertebraria wood.

The hourglass-shaped zone of secondary xylem tracheids observed in one of the Vertebraria specimens is comparable to ones described by Artabe and Zamuner (2007) in corystosperm wood from the Triassic of Argentina. The exact cause of these structures is unknown. In the absence of any trace of a wound, this may be the result of a particular cambial activity in which the number of derivatives in a zone is temporally reduced. This structure is not associated with a growth ring or with the closure of a lacuna.

Secondary phloem of Vertebraria is composed of longitudinally elongated cells with thick walls and rare uniseriate parenchymatous rays. The elongate cells are assumed to represent sieve cells. Studies of phloem anatomy in the Carboniferous gymnosperms Callistophyton (Russin 1981; Smoot 1984) and Cordaites (Taylor 1988) showed that although there may be quantitative differences, the secondary phloem of stem and root had a similar anatomy. Pigg and Taylor (1993) note the presence of five to eight cell layers of secondary phloem in Glossopteris skaarensis, but the poor preservation of this tissue does not allow a comparison to the phloem of Vertebraria.

\section{Growth Rings and Environment}

Permian plants from Antarctica grew in an environment that has no modern analog. With a paleolatitude estimated from paleogeographical reconstructions (Scotese 2002) to be between $80^{\circ}$ and $85^{\circ} \mathrm{S}$, the growing period was constrained by a strong seasonal light regime (Taylor and Ryberg 2007). The growth rings present in Vertebraria are characterized by a small amount of latewood characterized by only two to four tracheids with a reduced radial diameter and no significant increase in wall thickness. It is significant that anatomically similar types of rings are present in Araucarioxylon trunks from the same locality. Taylor and Ryberg (2007) interpreted this type of ring as demonstrating what must have been a very rapid 

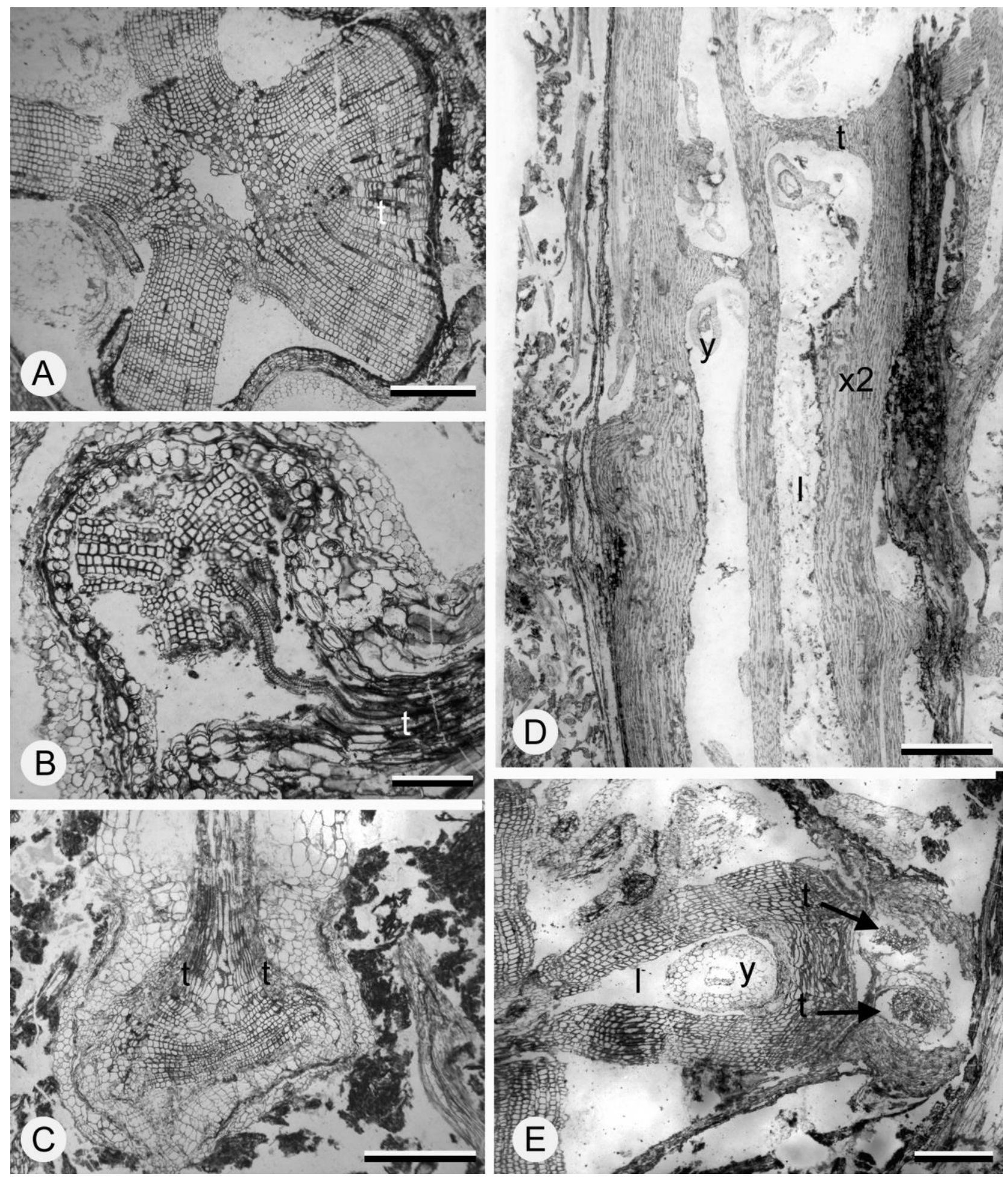

Fig. 8 Production of lateral roots in Vertebraria. A, Branching in a pentarch root. The vascular trace to the lateral root is occluding the lacuna on the right. Slide 23182, scale bar $=500 \mu \mathrm{m} . B$, Branching in a young triarch root showing primary xylem connection between primary and lateral root. Slide 23168, scale bar $=200 \mu \mathrm{m}$. C, Branching in a diarch root. The secondary vascular tissues of the wood wedges adjacent to the trace are connected to the lateral root. Slide 23248 , scale bar $=500 \mu \mathrm{m} . D$, Longitudinal section of axis with secondary growth illustrating how the vertical continuity of lacunae is interrupted by the traces to lateral roots. It is this aspect that gives Vertebraria a vertebral-like morphology when found compressed. Note the young roots growing inside the lacunae. Slide 26371, scale bar $=2 \mathrm{~mm}$. E, Transverse section of a root producing two laterals (arrows) from the same zone. Slide 23256, scale bar $=500 \mu \mathrm{m}$. $l=$ lacuna; $t=$ vascular trace to lateral root; $y=$ young roots; $x 2=$ secondary xylem. 
transition to seasonal dormancy, probably in response to decreasing light levels. Although there are very few studies comparing growth rhythms in roots and stems of the same plant, it appears that the cambium of tree roots and trunks can show comparable annual dynamics but with different intra-annual dynamics (Thibeault-Martel et al. 2008). In the case of Vertebraria, the false rings may represent local environmental variations, such as changes in the water table, while the true rings may reflect growth rhythms of the whole plant.

\section{Nature and Activity of the Vascular Cambium}

There are several examples of extant roots where the secondary tissue in the zones facing the protoxylem poles is different from the remainder of the wood. For example, roots of Actaea (Ranunculaceae) are well known for possessing wide parenchymatous rays that are produced opposite the protoxylem strands and divide the wood in sectors (Jeffrey 1917). In young roots of the New Zealand epiphyte Griselinia lucida (Griseliniaceae), the cambium facing the protoxylem produces large rays that separate the secondary xylem into wedges (Dawson and King 1966; Philipson et al. 1971). In older roots of G. lucida, the sectors of the cambium that produced these rays no longer produce parenchyma, and the rays are replaced by "normal" xylem. This situation is apparently comparable to what we observe in Vertebraria, with the presence of wedges of wood separated by parenchyma and a transition to a complete cylinder of wood in older roots. The anatomy and formation of the lacunae, however, seem incompatible with the idea of a continuous cambium that produces different derivatives. First, the parenchyma present in the lacunae of medium-sized roots (e.g., fig. $2 C$ ) is never radially aligned like the parenchyma produced by the cambium in extant roots (and stems) with distinct derivatives. Second, the parenchyma in Vertebraria is stretched and destroyed during the radial growth of the wood spokes, while parenchyma produced by a continuous cambium has a growth rate comparable with that of the woody sectors. These two observations imply that there are no cambial derivatives in the areas corresponding to the lacunae.

Developmental studies of extant plants show that the vascular cambium in roots typically appears first as a discontinuous layer located on the inner side of the primary phloem strands, in between the arms of primary xylem; secondary growth begins in these zones (Esau 1965). The cylinder of cambium is then completed by the differentiation and division of pericycle cells around the ends of the arms of primary xylem. This forms a smooth cylinder very early in development, and the areas facing the protoxylem strands are usually indistinguishable from the remainder of the axis. In some cases, they can be characterized by a small empty space corresponding in radial diameter to a few secondary xylem tracheids. On the basis of this information, it is easy to envisage how the typical structure of Vertebraria might have formed by simply extending the duration of the discontinuous cambium stage of development. A discontinuous vascular cambium in Vertebraria was first suggested by Neish et al. (1993). Our observations suggest that the earliest, discontinuous stage of cambial activity in Vertebraria persisted for a longer period of time than seen in other extant or fossil roots. The presence of growth rings in Vertebraria roots shows that the cambium remained discontinuous through several growth seasons and, based on the number of larger roots studied, probably through most of the life of some roots.

It has been suggested that the closing of the lacunae was the result of the enlargement of adjacent wedges of wood that finally came into contact (Neish et al. 1993). While this pattern has been observed in one specimen from Skaar Ridge, it is apparently linked to the anatomical changes related to the transition between root and stem. In other specimens with closed lacunae, closure took place before the wedges of wood were enlarged sufficiently to come in contact. This gives the external border of the lacunae a truncated shape instead of the pointed shape that would be produced if two adjacent wedges came in contact. Moreover, the enlargement of wood wedges could be very slow, and some specimens show up to 50 radial layers of secondary tracheids with almost no lateral enlargement. This suggests that there was no rapid enlargement of the cambial arcs.

The closing of the lacunae is thus apparently the result of the differentiation of a cambial zone, which produces vascular tissue from the parenchyma cells bordering the lacunae. This zone connects with the adjacent wedges to form a continuous cylinder. The existence of such a phenomenon was initially hypothesized by Schopf (1965) but was not described in detail or illustrated. Nevertheless, the origin of these parenchymatous cells remains unidentified. In extant plants, a new vascular cambium can originate in the phelloderm (e.g., in Welwitschia; Carlquist and Gowans 1995). New well-preserved specimens of Vertebraria showing the earliest stage of closure of the lacunae are now needed to investigate the possible existence of a similar origin of these cells in Vertebraria.

\section{Tissue Repartition and Possible Role(s) of the Lacunae}

As noted by previous authors, the lacunae in Vertebraria were apparently empty at maturity, except for the parenchymatous cells along the outer border. Plants growing in wetlands and waterlogged soils are often characterized by roots with an aerenchymatous primary or secondary cortex (Kozlowski 1997; Seago et al. 2005). This anatomy apparently provides for circulation of air in the axis. On the basis of this model, the lacunae of Vertebraria have been interpreted as a system of air circulation channels through an underground root system growing in an anoxic environment (Gould 1975). To function in such a system, there are several prerequisites: (1) the lacunae would have to be airtight; that is, there would be no diffusion of air through the cortex/periderm; (2) when traces to lateral roots are produced, which cross the lacunae, longitudinal air circulation would have to be maintained; and (3), the lacunae of the roots would have to be connected to air-conducting tissues in aerial parts of the plant. Since there is no evidence that all these conditions are met in Vertebraria, the aeration aspect of the lacunae must be considered with caution.

The analyses of the root cross-sectional area show that until the lacunae close most of the root is composed either of parenchymatous or empty zones. In the absence of lacunae, the vascular tissues would theoretically represent more than $80 \%$ of the cross-sectional area in Vertebraria roots with secondary growth. With lacunae present, however, this percentage is significantly lower $(<50 \%)$ in medium-sized roots in which the lacunae are not closed. Thus, there is a trade-off between the 
presence of large lacunae, possibly facilitating growth in anoxic or oligoxic conditions, and both hydraulic conduction and mechanical stiffness of the axes. The reduction in hydraulic conduction could be a factor limiting the capacity of the plants to grow in dry environments. It is also interesting to note that in extant plants the alternation of parenchymatous and woody sectors is usually found in lianas and some aerial roots (such as those of Griselinia lucida; see Dawson and King 1966). Current evidence indicates that all Vertebraria axes were probably roots. Even the largest specimens, where the primary vascular anatomy is not preserved, exhibit branching typical of roots. Moreover, there is some evidence of anatomical connection between Vertebraria and axes with a typical stem anatomy. However, we cannot exclude the possibility that Vertebraria roots were partly aerial.

\section{Future Directions}

From the evidence that has been assembled to date, it is clear that the genus Vertebraria represents roots with a highly unusual anatomy. Its characteristics are not so peculiar, however, if we consider that the vascular cambium of these roots remained discontinuous longer than in any other roots. The study of the specimens from Skaar Ridge provides some new information on Vertebraria but also raises some developmental questions that need to be addressed in future investigations as specimens become available. First, what are the factors affecting the activity of the vascular cambium in Vertebraria, and more specifically, what developmental or environmental triggers initiate closing of the lacunae? As noted in the description, the closure of the lacunae does not seem to depend on the diameter of the axis, as some large specimens have unclosed lacunae. Cambial activity could be influenced by changes in environmental factors during growth. The presence of the lacunae may have facilitated gas transport but produced flexible axes with reduced hydraulic capacities. Each of these characteristics could have been regulated by changes in the aeration, water content, or mechanical properties of the substrate in which Vertebraria roots were growing. Although the material described here is from a fossilized peat swamp, Vertebraria and Glossopteris have been found in a variety of depositional environments (Cúneo et al. 1993).

Second, evidence of an anatomical connection between Vertebraria and an axis bearing Glossopteris leaves is still lacking in the material from Skaar Ridge. Evidence from association seems reasonable, since glossopterid remains are by far the most abundant in the locality and similar associations are well documented throughout Gondwana (Pigg and Nishida 2006). It is still questionable, however, whether all Glossopteridales had Vertebraria-type roots. The presence at Skaar Ridge of two species of Glossopteris leaves (Pigg 1990) and at least three types of ovules indicates that the Glossopteridales were a diverse group. Yet, it is not possible to distinguish several types of Vertebraria roots in the material we examined. There are some gymnosperm roots in the Skaar Ridge material without lacunae ("solid-cylinder Vertebraria" of Neish et al. 1993). These roots are far less abundant than Vertebraria and generally occur in small clusters. Investigations of the architecture of Vertebraria root systems at a larger scale would be expected to clarify connections to distinct types of stems and the relationship of the typical root to the solid-cylinder type. In any case, the possession of a specialized rooting system in one or all representative of the group should be taken into account in future investigations of the success of glossopterid gymnosperms during the Permian and of their extinction in the Late Permian-Early Triassic.

\section{Acknowledgments}

We would like to thank J. L. Seago (Department of Biological Sciences, SUNY, Oswego) for helpful discussions on root anatomy. This research was supported by the National Science Foundation (OPP-0635477).

\section{Literature Cited}

$\rightarrow$ Artabe AE, AB Zamuner 2007 Elchaxylon, a new corystosperm based on permineralized stems from the Late Triassic of Argentina. Alcheringa 31:85-96.

$\rightarrow$ Beck CB 1953 A new root species of Callixylon. Am J Bot 40:226233.

2005 An introduction to plant structure and development: plant anatomy for the twenty-first century. Cambridge University Press, Cambridge.

$\rightarrow$ Carlquist S, DA Gowans 1995 Secondary growth and wood histology of Welwitschia. Bot J Linn Soc 118:107-121.

Cridland AA 1964 Amyelon in American coal-balls. Palaeontology 7:186-209.

Cúneo NR, J Isbell, EL Taylor, TN Taylor 1993 The Glossopteris flora from Antarctica: taphonomy and paleoecology. Pages 13-40 in $\mathrm{S}$ Archangelsky, ed. 12 Congrès International de Géologie du Carbonifère-Permian. Vol 2. Comptes Rendus, Buenos Aires.

Dawson JW, MD King 1966 Vegetative features of Griselinia lucida-a New Zealand shrub epiphyte. Tuatara 14:121-129.

Denne MP 1989 Definition of latewood according to Mork (1928). IAWA Bull 10:59-62.
Esau K 1965 Page 506 in Plant anatomy. Wiley, New York.

$\rightarrow$ Farabee MJ, EL Taylor, TN Taylor 1991 Late Permian palynomorphs from the Buckley Formation, central Transantarctic Mountains, Antarctica. Rev Palaeobot Palynol 69:353-368.

Galtier J, TL Phillips 1999 The acetate peel technique. Pages 67-70 in TP Jones, NP Rowe, eds. Fossil plants and spores: modern techniques. Geological Society, London.

Gould RE 1975 A preliminary report on petrified axes of Vertebraria from the Permian of eastern Australia. Pages 109-115 in KSW Campbell, ed. Gondwana geology. Australian National University Press, Canberra.

$\rightarrow$ Gould RE, T Delevoryas 1977 The biology of Glossopteris: evidence from petrified seed-bearing and pollen-bearing organs. Alcheringa 1:387-399.

$\rightarrow$ Halket AC 1932 A note on the origin of lateral roots and the structure of the root-apex of Lyginopteris oldhamia. New Phytol 31:279-283.

$\rightarrow$ IAWA Committee 2004 IAWA list of microscopic features for softwood identification. IAWA J 25:1-71.

Jeffrey EC 1917 Pages 156-157 in The anatomy of woody plants. University of Chicago Press, Chicago. 
Kozlowski TT 1997 Responses of woody plants to flooding and salinity. Tree Physiol Monogr 1:1-29.

$\rightarrow$ Krings M, S Schultka 2000 Ein besonderes Abdruckfossil von Lyginopteris aus dem Oberkarbon Westfalens, Deutschland. Feddes Repert 111:375-383.

McCoy F 1847 On the fossil botany and zoology of the rocks associated with the coal of Australia. Ann Mag Nat Hist 20:145-147.

$\rightarrow$ Neish PG, AN Drinnan, DJ Cantrill 1993 Structure and ontogeny of Vertebraria from silicified Permian sediments in East Antarctica. Rev Palaeobot Palynol 79:221-244.

Oldham RD 1897 On a plant of Glossopteris with part of the rhizome attached, and on the structure of Vertebraria. Rec Geol Surv India 30:45-50

Pant DD 1956 On two compressed Palaeozoic axes: Stigmaria ficoides in the Gymnostrobus condition and Vertebraria indica. Ann Bot 20:419-429.

Pant DD, RS Singh 1968 The structure of Vertebraria indica Royle. Palaeontology 11:643-653.

$\rightarrow$ Philippe M, MK Bamford 2008 A key to morphogenera used for Mesozoic conifer-like woods. Rev Palaeobot Palynol 148:184-207.

Philipson WR, JM Ward, BG Butterfield 1971 Page 92 in The vascular cambium: its development and activity. Chapman \& Hall, London.

$\rightarrow$ Pigg KB 1990 Anatomically preserved Glossopteris foliage from the central Transantarctic Mountains. Rev Palaeobot Palynol 66:105127.

$\rightarrow$ Pigg KB, H Nishida 2006 The significance of silicified plant remains to the understanding of Glossopteris-bearing plants: an historical review. J Torrey Bot Soc 133:46-61.

$\rightarrow$ Pigg KB, TN Taylor 1993 Anatomically preserved Glossopteris stems with attached leaves from the central Transantarctic Mountains, Antarctica. Am J Bot 80:500-516.

Rasband WS 1997-2008 ImageJ. U.S. National Institutes of Health, Bethesda, MD. http://rsb.info.nih.gov/ij/.

$\rightarrow$ Raven JA, D Edwards 2001 Roots: evolutionary origins and biogeochemical significance. J Exp Bot 52:381-401.

Rothwell GW 1975 The Callistophytaceae (Pteridospermopsida). I. Vegetative structures. Palaeontographica B 151:171-196.

$\rightarrow$ Rothwell GW, KL Whiteside 1974 Rooting structures of the Carboniferous medullosan pteridosperms. Can J Bot 52:97-102.

Royle JF 1839 Illustrations of the botany and other branches of the natural history of the Himalayan Mountains and of the flora of Cashmere. Vol 2. Allen, London. $\rightarrow$ Russin WA 1981 Secondary phloem of the Paleozoic pteridosperm Callistophyton boyssetii. Bot Gaz 142:165-175.

Schopf JM 1965 Anatomy of the axis in Vertebraria. Pages 217-228 in JB Hadley, ed. Geology and paleontology of the Antarctic. American Geophysical Union, Washington, DC.

1970 Petrified peat from a Permian coal bed in Antarctica. Science 169:274-277.

$\rightarrow-1982$ Forms and facies of Vertebraria in relation to Gondwana coal. In Geology of the Central Transantarctic Mountains. Ant Res Series 36:37-62.

Scotese CR 2002 PALEOMAP Project. http://www.scotese.com.

$\rightarrow$ Seago JL, LC Marsh, KJ Stevens, A Soukoup, O Votrubova, DE Enstone 2005 A re-examination of the root cortex in wetland flowering plants with respect to aerenchyma. Ann Bot 96:565-579.

$\rightarrow$ Sen J 1955 Structure of Vertebraria. Nature 175:176.

1958 Further studies on the structure of Vertebraria. Bot Not 111:436-448.

Seward AC 1914 Antarctic fossil plants. British Antarctic ("Terra Nova”) Expedition, 1910. Natural History Report. Geol 1:1-49.

Smoot EL 1984 Secondary phloem anatomy in Callistophyton boyssetii (Renault) Rothwell and histological changes in the outer phloem. Bot Gaz 145:395-406.

Steidtmann WE 1944 The anatomy and affinities of Medullosa noei Steidtmann, and associated foliage, roots, and seeds. Contrib Mus Paleontol Univ Mich 6:131-166.

Taylor EL 1988 Secondary phloem anatomy in cordaitean axes. Am J Bot 75:1655-1666.

$\rightarrow$ Taylor EL, PE Ryberg 2007 Tree growth at polar latitudes based on fossil tree ring analysis. Palaeogeogr Palaeoclimatol Palaeoecol 255:246-264.

$\rightarrow$ Thibeault-Martel M, C Krause, H Morin, S Rossi 2008 Cambial activity and intra-annual xylem formation in roots and stems of Abies balsamea and Picea mariana. Ann Bot 102:667-674.

Walton J, JAR Wilson 1932 On the structure of Vertebraria. Proc R Soc Edinburgh 52:200-207.

White ME 1973 Permian flora from the Beaver Lake area, Prince Charles Mountains, Antarctica. 2. Plant fossils. Bull Bur Mineral Resour Geol Geophys 126:13-18.

$\rightarrow$ Williamson WC 1894 The root of Lyginodendron oldhamium, Will. Proc R Soc Lond B 56:128.

Zeiller R 1896 Etude sur quelques plantes fossiles, en particulier Vertebraria et Glossopteris des environs de Johannesburg (Transvaal). Bull Soc Geol France Ser 3 24:349-378. 